\title{
Students' Perceptions to Introduction of Problem-based Learning Modules in Anatomy
}

\author{
${ }^{1}$ Punita Sharma, ${ }^{2}$ Kanika Sachdeva
}

\begin{abstract}
Introduction: It is necessary for core knowledge of anatomy to be assimilated by all doctors in order to practice, but if it can improve their understanding of what they do and why they do it, this surely has to be of benefit for both the safety of the patient and satisfaction of the doctor as a professional. This intervention aimed to study whether problem-based learning $(\mathrm{PBL})$ as an educational strategy can help in improving the quality of gross anatomy teaching and the attitude of students toward the learning method in India.
\end{abstract}

Materials and methods: The study sample included 100 students who were assigned to 10 groups (10 students in each group). Each PBL tutorial was conducted over three sessions. Pre- and post-tutorial tests were conducted. Data collection was done by a questionnaire survey to examine the students' learning attitudes and perceptions toward this platform as a possible learning tool. The obtained data were compared, and the main themes were determined.

Results: We found out the satisfaction of students with this learning method and the students' interest and ability for improvement after this teaching method. Also, the problems and obstacles the students faced in this learning mode were highlighted.

Conclusion: The study clearly pointed out that PBL benefits a lot of students in the study of gross anatomy despite the existing problems. In future, we should implement PBL combined with the characteristics of traditional anatomy teaching.

Keywords: Facilitator, Problem-based learning, Self-directing learning, Student-centered teaching.

How to cite this article: Sharma P, Sachdeva K. Students' Perceptions to Introduction of Problem-based Learning Modules in Anatomy. Curr Trends Diagn Treat 2017;1(1):42-45.

Source of support: Nil

Conflict of interest: None

\section{INTRODUCTION}

Physicians are required to have cognitive abilities that include problem-solving skills, decision-making skills,

\footnotetext{
${ }^{1}$ Professor, ${ }^{2}$ Assistant Professor

1,2Department of Anatomy, Sri Guru Ram Das Institute of Medical Sciences and Research, Amritsar, Punjab, India

Corresponding Author: Punita Sharma, Professor, Department of Anatomy, Sri Guru Ram Das Institute of Medical Sciences and Research, Amritsar, Punjab, India, e-mail: punitasalwan@ gmail.com
}

and sound clinical judgment. They also have a societal obligation to maintain their knowledge and skills by engaging in lifelong learning. ${ }^{1}$ Many physicians' organizations have identified learning as a lifelong activity and have accepted the need to become a self-directed learner as an essential competency, recommending that these competencies should be improved and evaluated throughout the education of physicians. ${ }^{1-3}$ Correspondingly, medical educators have sought to ensure that students are well equipped with the necessary self-regulated learning skills to cope with the continued exponential growth in medical knowledge. ${ }^{4}$

In recent years, one of the major innovations in medical education has been problem-based learning (PBL). Problem-based learning, as used in medical education, has specific purpose, features, and outcomes and has been used as a driving force to generate curriculum reform through concentration on a single curriculum element. ${ }^{5}$ Problem-based learning was first employed in the 1960s in the Medical Education Department at McMaster University' Faculty of Health Sciences, Canada, and soon after, other medical schools in Netherlands, United States, and Australia followed. ${ }^{6}$ This type of teaching, based on research by Barrows in the 1960s, seeks to integrate basic sciences and clinical teaching, leading to the acquisition of an integrated knowledge base, i.e., readily recalled and applied to the analysis and solution of problems. ${ }^{7}$

Problem-based learning aims to develop effective self-directedness ${ }^{8}$ and helps students to develop effective problem-solving skills and to become active participants in their own learning by enabling them to construct knowledge. ${ }^{9,10}$ In PBL, students learn content and strategies and develop self-directed learning skills by collaboratively solving problems, reflecting on their experiences, and engaging in self-directed inquiry. ${ }^{11-14}$

Problem-based learning is an innovative and challenging approach to medical education; innovative because it is a new way of using learning material to help students learn, and challenging because it requires the teacher to use facilitating and supporting skills rather than didactic, directive ones. ${ }^{15,16}$ It is an approach much favored by curriculum planners in new and more progressive academic institutes. ${ }^{17}$ It is a worldwide common opinion that anatomy must be taught and learnt in such a way 
that it becomes clinically meaningful and is related to the competences required by new medical graduates so that the students understand its relevance to their future practice. $^{18}$

So, the present study was undertaken to introduce PBL modules for clinically relevant topics in the Department of Anatomy at a tertiary care hospital and medical college in Amritsar; the study was conducted with the sole purpose of introducing students and teachers to the new teaching-learning modality and evaluate the perceptions of students regarding its significance and future modification of the PBL modules. Till date, apart from didactic lectures, small groups of teaching strategies / modalities have been used in the department, though not in a planned and focused manner. So, it was high time to introduce, in a phased manner, a time-tested modality (PBL) and evaluate it for future planning and implementation.

\section{MATERIALS AND METHODS}

The study was conducted for a batch of 100 students from session 2011 to 2012. The study was duly approved by the Institutional Research and Ethics Committee. The faculty and students were oriented and introduced to the concept of PBL and group discussion through interactive power point presentations. All participants were informed of the purpose and design of the study. Each student was assured that the data obtained and their identities would be confidential and anonymous. All students willingly participated in the study, and no control group was formed due to ethical issues. Informed written consent was obtained from all the students. Modules on four paper-based clinical scenarios were given as problems, which were prepared for head and neck and abdomen of gross anatomy by trained faculty of the anatomy department in consultation with the surgical department. Each PBL module comprised three sessions. The present study not only addressed the students' perceptions but also tested the level of acquired knowledge.

\section{Outline of the PBL Module}

- Pretest taken is given as a multiple choice question (MCQ) test.

- The paper-based PBL scenario/case is given to the allocated groups of 10 to 12 students (Session 1).

- Students familiarized themselves with the case and formulated learning goals that were arrived at after brainstorming. Possible explanations for the main issues that they had identified for the case were generated.

- Learning objectives were defined by each group at the end of Session 1.
- Students were expected to realize these learning goals by means of self-study using a variety of resources available to them, including library books and journals, the Internet, etc. (Students were given 3 to 4 days duration for clarifying the concepts using various resources).

- Students reported back on their findings, shared and pooled their knowledge, and evaluated their own learning in Session 2.

- Facilitators made sure that the discussion was within the precincts of learning objectives and students clarified their doubts with each other and with their teacher.

- The students assembled for the final presentation (power point) in a large group for Session 3 and facilitators clarified doubts.

- Posttest is taken MCQ.

- Student feedback questionnaire survey was done. Students followed the principles of group dynamics by appointing a leader, scribe, timekeeper, and reporter to conduct fruitful discussions in each session. Thus, they were also accustomed to the principles of group dynamics.

\section{RESULTS AND DISCUSSION}

Descriptive analysis of students' responses collected through prevalidated feedback questionnaire was performed. The questionnaire contained 12 structured questions and three open-ended questions, which were intended to elicit comments regarding advantages and fallouts of PBL modules and suggestions for improvement. When the module was conducted, 94 students participated (six students were not able to complete the module due to absenteeism), and 84 students responded to feedback questionnaire $(90 \%$ response rate). For the purposes of reporting and discussing the results, the percentage of student's responses has been rounded off to the nearest whole number.

As evident from Table 1, the percentage of students agreeing to most of the questions posed to them was in the range of 46 to $91 \%$. Majority of students perceived that PBL helped in improved grasping of subject (89\%), brought in more interactions among students (85\%), can be used with lectures in tandem $(86 \%)$, and will be helpful in clinical years (90\%). The process of underpinning PBL is based on a cognitive perspective of "how we learn." It emphasizes the key activities of activating prior knowledge, learning in context, and elaboration. ${ }^{19}$ A total of 59\% students felt that it will help them perform better in university exams. It was a perception based on students' acquisition of knowledge though not proven. And, $72 \%$ respondents perceived that PBL helps to 
Table 1: Students responses to 5-point Likert scale questionnaire. Total number of respondents $(n=84)$

\begin{tabular}{|c|c|c|c|c|c|c|}
\hline $\begin{array}{l}\text { SI. } \\
\text { no. }\end{array}$ & Questions & $\begin{array}{l}\text { Strongly } \\
\text { disagree (\%) }\end{array}$ & $\begin{array}{l}\text { Agree } \\
(\%)\end{array}$ & $\begin{array}{l}\text { Uncertain } \\
\text { (\%) }\end{array}$ & $\begin{array}{l}\text { Disagree } \\
(\%)\end{array}$ & $\begin{array}{l}\text { Strongly } \\
\text { agree (\%) }\end{array}$ \\
\hline 1 & PBL tutorial helped in better grasp of subject & 80 & 9 & 8 & 3 & \\
\hline 2 & Group discussion brought in more interaction among subjects & 79 & 6 & 6 & 8 & 1 \\
\hline 3 & PBL can be used along with lectures to teach anatomy & 83 & 3 & 6 & 8 & \\
\hline 4 & PBL tutorials will help in better clinical knowledge later & 80 & 10 & 10 & - & \\
\hline 5 & It helps in better performance in university exams & 50 & 9 & 29 & 12 & \\
\hline 6 & It can be used to teach other topics of anatomy & 74 & 4 & 10 & 12 & \\
\hline 7 & It can be used to teach other subjects as well & 73 & 8 & 7 & 12 & \\
\hline 8 & Small group discussion improves problem-solving ability & 62 & 10 & 18 & 8 & 2 \\
\hline 9 & Facilitators were helpful during group discussion & 80 & 3 & 10 & 7 & \\
\hline 10 & PBL was conducted in a systematic manner & 41 & 9 & 31 & 19 & \\
\hline 11 & $\begin{array}{l}\text { PBL module gives an opportunity to clarify doubts and express } \\
\text { one's thoughts }\end{array}$ & 40 & 6 & 32 & 22 & \\
\hline 12 & Presentations from each group helped me learn better & 62 & 6 & 18 & 14 & \\
\hline
\end{tabular}

improve problem-solving skills. It is not necessary to solve the problem, but the experience of gathering and learning the information to support an understanding of the problem is where learning occurs. ${ }^{20}$

A moderate response was garnered for systematic conduct of tutorial (50\%). One of the main reasons is lack of experience on the part of faculty and students to understand and conduct the group activity. A total of $83 \%$ of students felt that facilitators were helpful. Facilitation in PBL is particularly challenging since the tutor should provide as little guidance as possible while at the same time not allow the students to get lost. Role of tutor moves from didactic dispensing of facts toward being a somewhat privileged and outside group member who steers the group to enhance group dynamics. Gilkison ${ }^{21}$ indicates the importance of tutors' roles of "raising students' awareness" and "facilitating the group processes" in a PBL setting. The facilitator should be able to shadow the discussion so as to keep a hawk's eye on the proceedings and also to not miss the points raised, their relevance in context, outcomes reached, and further readings planned.

Open-ended questions regarding what went well, what was still desired, and any suggestions were asked to the students to elicit elaborate student perception. Themes extracted from the qualitative analysis were broadly categorized (Table 2). A total of $54 \%$ students perceived that PBL helps to develop interactions among students and clarifying concepts, which were otherwise overlooked. The Questions that cropped up during the discussion help to make session more meaningful and learning-oriented. ${ }^{*}$ A total of $36 \%$ students opined that it helps to improve subject retention. This is in conformation with other studies. ${ }^{22-24}$ A total of 31\% students felt that an exposure to problem solving will give them an edge in clinical settings in subsequent years. We get an opportunity to train our minds for a similar environment during clinical terms.
Table 2: Theme-based analysis of open-ended questions

\begin{tabular}{rll}
\hline SI. & & \% of student \\
no. & Theme generated & 54 \\
\hline 1 & Concept clarification & 25 \\
2 & Collaborative learning & 54 \\
3 & Interactions among students & 31 \\
4 & Wider coverage of topic beyond the books & 36 \\
5 & Better retention of topic & 19 \\
6 & Confidence building occurs & 16 \\
7 & Generates interest in the subject & 31 \\
8 & Useful in clinical years & 13 \\
9 & Communication skills improved & 13 \\
10 & Strategic tackling skills developed & 6 \\
11 & Team work developed & 6 \\
12 & Final presentation is useful & 36 \\
13 & Less time for discussion & 80 \\
14 & Nonavailability of Internet and computers & 60 \\
15 & Lack of group dynamics & \\
\hline
\end{tabular}

To say that we encountered problems is wrong. Actually we encountered challenges. Problems are troublesome, but Challenges make us learn better. Because of the wide expanse of medical knowledge, the confidence of students plummets within the first few months of their entry into medical profession. This reduces their motivation and urge to excel, which is so evident in the beginning. A total of $19 \%$ students perceived the spike in their confidence levels after participating in PBL modules. One is able to know one's potential and explore the plethora of potential within. Some studies have demonstrated that PBL enhances students' intrinsic interest in the subject matter, strengthens students' self-directed learning skills, ${ }^{22}$ and is more nurturing and enjoyable. ${ }^{25}$ We can express our thoughts without HESITATION.

The major roadblock encountered, as fished out from student feedback, was the lack of Wifi facility in the campus $(80 \%)$. The students could access the library

*Students' verbatim responses are in italics. 
resources and journal, but the lack of Internet hindered the requisite progress intended. Other studies have also emphasized that PBL supplemented with e-learning will enhance the students' ability to learn collaboratively ${ }^{26}$ and noted increased interactivity of PBL sessions with "blended" curricula. ${ }^{27}$ Several steps have been initiated to expedite the Internet services in the institute. It will improve the participation of students in the subsequent years. A total of $36 \%$ students felt there was lack of adequate time for discussion to clarify doubts and browse through resources. This obstacle can be overpowered with efficient planning to use uncluttered time zones when not so difficult areas are dealt with in all the three subjects of the first year.

Lack of group dynamics $(60 \%)$ was envisioned as the students are inexperienced in small group discussions. They are more comfortable and aligned to passive, one-way communication of didactic format. A sustained effort will assist to track out dynamics among students.

\section{CONCLUSION}

Problem-based learning will assist not only to gain the desired knowledge incumbent of medical graduate but also inculcate skills, such as communication, critical reasoning, logical and analytical approach to problems, reasoned decision-making, and self-evaluation. Developing group dynamics will help in interdepartmental and interdisciplinary execution of projects. The suggestions given by students and the faculty discussions in the department will be very valuable for conducting PBL tutorials henceforth.

\section{ACKNOWLEDGMENT}

This is a part of the principal author's Faimer fellowship project. We highly acknowledge the cooperation and support of Faimer Faculty, CMC, Ludhiana, for their relentless mentoring and support.

\section{REFERENCES}

1. Artino AR, Dong T, DeZee KJ, Gilliland WR, Waechter DM, Cruess D, Durning SJ. Achievement goal structures and selfregulated learning: relationships and changes in medical school. Acad Med 2012 Oct;87(10):1375-1381.

2. Gabr H, Mohamed N. Effect of problem-based learning in undergraduate nursing students enrolled in nursing administration course. Int J Acad Res 2011 Jan;3(1):154-162.

3. Hoban JD, Lawson SR, Mazmanian PE, Best AM, Seibel HR. The self-directed learning readiness scale: a factor analysis study. Med Educ 2005 Apr;39(4):370-379.

4. Demirören M, Turan S, Öztuna D. Medical students' selfefficacy in problem-based learning and its relationship with self-regulated learning. Med Educ Online 2016 Mar;21:30049.

5. Schmidt HG. Problem-based learning: rationale and description. Med Educ 1983 Jan;17(1):11-16.
6. Distlehorst LH, Dawson E, Robbs RS, Barrows HS. Problembased learning outcomes: the glass half-full. Acad Med 2005 Mar;80(3):294-299.

7. Mitchell SR, Hinduja K, Samuel R, Hirst P. Anatomy for orthopaedics - is problem-based learning an effective teaching method? J Bone Joint Surg Br 2008 Apr;90(Suppl 1):16.

8. Groves M, Rego R, O'Rourke P. Tutoring in problem-based learning medical curricula: the influence of tutor background and style on effectiveness. BMC Med Educ 2005 Jun;5(1):20.

9. Savin-Baden, M. Facilitating problem-based learning: illuminating perspectives. Berkshire, England: Open University Press; 2003.

10. Maudsley G. Roles and responsibilities of the problem-based learning tutor in the undergraduate medical curriculum. BMJ 1999 Mar;318(7184):657-661.

11. De Grave WS, Dolmans D, van der Vleuten C. Profiles of effective tutors in problem-based learning: scaffolding student learning. Med Educ 1999 Dec;33(12):901-906.

12. Papinczak T, Tunny T, Young L. Conducting the symphony: a qualitative study of facilitation in problem-based learning tutorials. Med Educ 2009 Apr;43(4):377-383.

13. Schmidt HG, Moust JHC. What makes a tutor effective? A structural-equations modelling approach to learning in problem-based curricula. Acad Med 1995 Aug;70(8): 708-714.

14. Edelson DC. Learning-for-use: a framework for integration content and process learning in the design of inquiry activities. J Res Sci Teach 2001 Mar;38(3):355-385.

15. Lin CF, Lu MS, Chung CC, Yang CM. A comparison of problem based learning and conventional teaching in nursing ethics education. Nurs Ethics 2010 May;17(3):373-382.

16. Shin IS, Kim JH. The effect of problem-based learning in nursing education: a meta-analysis. Adv Health Sci Educ Theory Pract 2013 Dec;18(5):1103-1120.

17. Bligh J. Problem-based learning in medicine: an introduction. Postgrad Med J 1995 Jun;71(836):323-326.

18. Rani A, Chopra J, Pandey A, Srivastava AK, Sharma PK. Learning outcome analysis of preclinical MBBS students following teaching by anatomist and/or clinician. Ind J Basic App Med Res 2013;2(6):470-476.

19. Schmidt HG. Foundations of problem-based learning: some explanatory notes. Med Educ 1993 Sep;27(5):422-432.

20. Barrows, H.S.; Tarnblyn, R.M. Problem-based learning: an approach to medical education. New York: Springer; 1980.

21. Gilkison A. Techniques used by "expert" and "non-expert" tutors to facilitate problem-based learning tutorials in an undergraduate medical curriculum. Med Educ 2003 Jan;37(1):6-14.

22. Norman GR, Schmidt HG. The psychological basis of problembased learning: a review of the evidence. Acad Med 1992 Sep;67(9):557-563.

23. Berkson L. Problem-based learning: have the expectations met? Acad Med 1993 Oct;68(Suppl 10):79-88.

24. Hurtling L, Spooner C, Tjosvold L, Oswald A. Problem-based learning in pre-clinical medical education: 22 years of outcome research. Med Teach 2010 Jan;32(1):28-35.

25. Albanese MA, Mitchell S. Problem-based learning: a review of literature on its outcomes and implementation issues. Acad Med 1993 Jan;68(1):52-81.

26. Azer SA. Introducing a problem-based learning program: 12 tips for success. Med Teach 2011;33(10):808-813.

27. Donnelly R. Harmonizing technology with interaction in blended problem-based learning. Comput Educ 2009;54(2): 350-359. 